\title{
Coastal Zone Development Strategy as Tourism Object: A Case Study of Tapandullu Beach, Mamuju Regency
}

\author{
Nurul Idil Fitri ${ }^{1}$, Pengerang Moenta ${ }^{1}$, Rusnadi Padjung ${ }^{1}$ \\ nurul.idilfitri@gmail.com \\ ${ }^{1}$ Department of Regional Planning and Development, Hasanuddin University, Indonesia
}

\begin{abstract}
This study aims to determine the Coastal Zone Development Strategy as a Tourism Object in Mamuju Regency. This type of research is qualitative research using the exploratory method. In the selection of research, informants were carried out deliberately (purposive sampling) with as many as 7 informants. Data analysis with an interactive model consists of three stages of data reduction, data presentation, drawing conclusions. The results showed that the policy in developing the coastal area as a tourist destination in the Mamuju Regency area by increasing the promotion of regional tourism in Mamuju Regency, developing environmentally-based productive tourism, growing the active role of the community to participate in building the tourism sector, and increasing the role of local government, Private sector and society in tourism development in Mamuju regency. Factors that influence the development of tourism, namely the supporting factors in the management of tourist objects, namely the potential of the area and the active role of the community so that they can develop and build a tourist attraction for Tapandullu Beach that is better and can attract the attention of tourists. While the inhibiting factors in Tapandullu Beach Tourism Governance are inadequate facilities and infrastructure and limited budget so that it hinders the process of developing the Tapandullu Beach tourism object. The managerial strategy for developing tourist beach tourism is realized in the form of strengthening the mass tourist market segment and developing the tourism market segment to optimize the development of coastal tourism destinations.
\end{abstract}

Keywords: Tourism, Beach, SWOT, Local Government

Received: December 20, 2020

Revised: January 2, 2021

Accepted: January 8, 2021

\section{Introduction}

The development of the tourism sector is a realistic and logical action, given the positive impact it has had, including the expansion of business opportunities, including hotels, travel agencies, souvenir shops as well as increased public opinion and encouraging the maintenance of security and order even though there are actually things that are "also". negative impact (Heryati, 2019).

Areas with tourism potential can revive the economic activities of the surrounding community with the emergence of small to medium scale businesses, reduce unemployment, increase community income, and increase local revenue (PAD) which will be used again by the government to carry out development in the area and achieve prosperity (Nawawi, 2005; Adrianus \& Labuda, 2018). In developing the tourism potential of Tapandullu Beach in Mamuju Regency, many factors influence the success or failure of its development, which has a lot of tourism potential which includes natural tourism.

Mamuju Regency has many interesting places to be used as tourist objects. Because the potential for tourism objects is not paid attention and is developed so that the potential is not visible to other areas, so tourists who visit Mamuju Regency are only domestic tourists.

Copyright @ 2021, International Journal Papier Public Review, Under the license CC BY-SA 4.0 DOI: https://doi.org/10.47667/ijppr.v2i1.71 
During 2016 the number of domestic tourists was 24,314 and foreign tourists were 24,300 , in 2017 the number of domestic tourists was 16,400 and foreign tourists were 16,339. in 2018 the number of domestic tourists was 15,100 and foreign tourists as many as 70 , it can be seen that tourist visitors in the Regency tend to experience a decline.

Based on this, it is necessary to establish strategies and policies aimed at encouraging the development and development of tourism activities. These policies must accommodate the principles of sustainable tourism, covering job creation, conservation of natural resources, maintaining and improving the quality of life and local welfare (Northcote \& Macbeth, 2006; Edgell, 2019).

It is hoped that the progress of tourism objects in Mamuju Regency, especially the Tapandullu Beach Tourism Object, is in line with the improvement of the welfare of the community around the coast (Febrianty, 2017). The progress of tourism must be able to provide economic progress for the community around the tourism object (Milne \& Ateljevic, 2001; Liu, 2003; Choi \& Sirakaya, 2006). This must be resolved by all groups, both government and stakeholders who play an important role in the world of tourism.

Based on the background above, considering the complex problems of coastal areas, nature, characteristics, and dynamics of coastal areas, the existence of Law No.1 of 2014 concerning the management of coastal areas and small islands is very strategic to realize sustainable management of coastal and island resources - small islands and improve the welfare of people who live in coastal areas. This law includes granting the right to the community to propose the preparation of a Strategic Plan, Zoning Plan, Management Plan, and Coastal Zone Management Action Plan.

\section{Methods}

This research is field research (Field Research) with a qualitative approach that aims to explore facts about strategies in developing the potential of the coastal area as a tourist attraction in Mamuju Regency. This research was conducted at Tapandullu Beach, Mamuju Regency. The selection of research informants was carried out deliberately (purposive sampling) and based on the basis of suitability in accordance with the needs of research data and information.

This study uses primary data and secondary data. Primary data is data obtained directly from research informants who have been determined in accordance with research variables through observation and in-depth interviews related to the development of coastal areas. Secondary data is data obtained in writing through a review of important documents related to the development of coastal areas such as tourism visit data, tourism PAD for 2015-2019, tourist guide booklets, regional regulations related to tourism development, and medium-term development plans. This document is used as the basis for crosschecking the primary data that has been obtained.

The data analysis technique used in this research is descriptive analysis. This analysis means that the data obtained from the research are presented as they are then analyzed exploratively to get a picture of the facts that occur. There are two analysis models used, namely interactive model data analysis and descriptive data analysis.

\section{Results and Discussion}

The problem is an indicator of research on the strategy of developing coastal areas as a tourism object in Tapandullu Beach, Mamuju Regency. The strategic policy for the Tapandullu Beach area as a tourist destination in Mamuju Regency. The National Tourism Development Policy is regulated in Law Number 10 of 2009 concerning Tourism. The policy 
is then outlined in the Mamuju Regency Regional Regulation Number 5 of 2016 concerning the Mamuju Regency Medium Term Development Plan (RPJMD) 2016-2021 which is contained in the 5th mission: realizing Mamuju as an open area, the goal is to make Mamuju a tourism and cultural development area., the target is to improve the management of the tourism and cultural potential of Mamuju Regency.

Mamuju Regency does not have specific regional regulations related to tourism destination management so that in its implementation it is still guided by the Regional Regulation (PERDA) Retribution for Recreation and Sports Places Number 14 of 2011. Based on the results of interviews and document review, the budget from 2016 to 2018 is insufficient to develop Mamuju Regency Tourism Destinations, not only not enough to finance the development of tourist destinations as a whole, even to finance the three leading tourism objects in Mamuju Regency is still not enough.

In the collaboration that is built, the government still plays as a key figure but does not dominate that has the capacity to coordinate (not mobilize) actors in semi-non-governmental institutions to achieve public goals. In developing the potential of the Tapandullu Beach Tourism Object in Mamuju Regency, many factors influence the success or failure of its development, which has a lot of tourism potential which includes natural tourism. The Government of Mamuju Regency until now continues to carry out promotions for the introduction of tourism, which every year

\section{Influencing factors in the development of Tapandullu Beach tourism in Mamuju Regency}

The regional potential is a wealth that is owned by an area as a source that can be extracted to produce a better quality of life. Mamuju Regency as a new autonomous region has a supply of natural resources that are so rich and not well explored that it can still be managed and developed as one of the regional assets.

Mamuju Regency has the availability of supporting tourism facilities that support the running of tours for tourists visiting Mamuju Regency such as the availability of restaurants, banks, airports, terminals, ports, travel agents. Even though until now there has been no cooperation with the local government, this facility still contributes to supporting tourism activities in Mamuju Regency. Tapandullu beach tourism object has the availability of supporting tourism facilities that are quite supportive.

Based on the results of the interview, it is known that an area such as Mamuju Regency which has a wealth of natural and cultural resources should be utilized by the community and the government, because it is not impossible that Mamuju Regency will become one of the main tourist destinations in West Sulawesi Province because of its cultural diversity and nature are protected.

\section{Active Role of Community}

A process that involves the community is generally known as community participation, which is a continuous two-way communication process to increase the full community understanding of an activation process, where environmental problems and needs are being analyzed.

\section{Managerial strategy for coastal development}

The strategy formulation process includes developing a vision and mission, identifying opportunities, threats, strengths, and weaknesses, setting long-term goals, searching for alternative strategies, and selecting strategies in the institution. Based on the results of interviews, observation, and document review, it can be concluded that the analysis of 
development strategies is based on the strengths, weaknesses of internal factors, and opportunities and threats from external factors. Furthermore, in the tourism development strategy, the search for alternative strategies is something that needs to be done by the local government (Joppe, 1996; Wilson et al., 2001; Dredge, 2006; Rogerson, 2020), especially by the Mamuju Regency Tourism and Culture Office. The choice of the strategy taken by the government in developing coastal tourism objects is to list priorities for coastal tourism development.

Table 1. Analysis of internal and external factors for tourism in Tapandullu Beach

\begin{tabular}{|c|c|}
\hline Opportunity & Threat \\
\hline $\begin{array}{l}\text { 1. A tourism development system that knows } \\
\text { no time, boundaries, and territories } \\
\text { 2. A well-managed tourist attraction will be } \\
\text { a continuous source of income } \\
\text { 3. The developed tourist attraction can } \\
\text { trigger the achievement of community } \\
\text { welfare } \\
\text { 4. Government policy in developing marine } \\
\text { tourism } \\
\text { 5. High tourist interest in visiting the beach } \\
\text { tourism } \\
\text { 6. Easy access to tourist information with the } \\
\text { internet } \\
\text { 7. Can be accessed by land }\end{array}$ & $\begin{array}{l}\text { 1. Local culture that can shift due to the } \\
\text { interaction of local people with tourists } \\
\text { 2. Environmental pollution in coastal areas } \\
\text { 3. Still lack investors } \\
\text { 4. Environmental pollution }\end{array}$ \\
\hline Strength & Weakness \\
\hline $\begin{array}{l}\text { 1. Potential tourist attraction/tourism object } \\
\text { 2. Communities that support tourism } \\
\text { development } \\
\text { 3. A government that really cares about } \\
\text { tourism } \\
\text { 4. It has a beautiful and clean beach } \\
\text { 5. Beach tourism is able to increase local } \\
\text { people's income }\end{array}$ & $\begin{array}{l}\text { 1. Internal tourism human resources and } \\
\text { tourism managers who still do not meet } \\
\text { several qualifications, } \\
\text { 2. Limited tourism facilities and } \\
\text { infrastructure, such as road access to } \\
\text { tourism objects } \\
\text { 3. Limited Budget } \\
\text { 4. Poorly maintained beach tourism facilities } \\
\text { 5. There is still a lack of massive promotion } \\
\text { of coastal tourism } \\
\text { 6. The level of security is still lacking } \\
\text { 7. Not yet developed beach tourism }\end{array}$ \\
\hline
\end{tabular}

The implementation of a strategy (implementation strategy) for the development of coastal tourism objects in Mamuju Regency requires the government to perform management functions. Based on the results of the interviews, it is known that the implementation strategy is in the form of management functions, which include planning, organizing, coordinating, and controlling. The Tourism and Culture Office coordinates with local governments and other institutions such as the Ministry of Tourism and Creative Economy.

The development of the tourism sector in the Mamuju Regency area is supported by Law No. 10 of 2009 concerning tourism which states that the existence of tourism objects in an area will be very beneficial, including increasing economic growth, increasing community welfare, preserving nature and the environment, strengthening national identity and fostering a sense of love the homeland. Then, as written in the Mamuju Regency Regional Regulation Number 9 of 2016 concerning the Mamuju Regency Medium Term Development Plan 
(RPJMD) for 2016-2021 it is explained that one of the goals and objectives of the Mamuju Regency mission is to make Mamuju Regency a tourism and cultural development area.

The several policies in developing coastal tourism in the Mamuju Regency area are as follows; (1) Increasing the promotion of regional tourism in Mamuju Regency, (2) Developing environmentally-based productive tourism, (3) Fostering an active role of the community to participate in building the tourism sector, (4) Increasing the role of the Government, private sector and society in developing tourism in the Regency Mamuju.

In Mamuju Regency itself, the Regional Original Revenue (PAD) generated by the Mamuju Regency Culture and Tourism Office from the tourism sector is still not optimal. In the tourism sector, it is only able to contribute around 50\% of the planned target from 2015 to 2017.

Based on the research results, the Tourism Office must be based on national policies, Long Term Development Plan (RPJP), Medium Term Development Plan (RPJM), Regional Long Term Development Plan (RPJPD), Regional Medium Term Development Plan (RPJMD), and Regional Apparatus Strategic Plan (Renstra PD). this is in accordance with the mandate of the Minister of Home Affairs regulation no.86 of 2017 concerning procedures for planning, controlling, and evaluating regional development, procedures for evaluating draft regional regulations concerning regional long-term development plans and regional mediumterm development plans, as well as procedures for changing development plans. long-term regional, regional medium-term development plans, and local government work plans, where the regional government has the obligation to determine the regional government's strategic plan for a five-year period (Nyoman, 2003).

Through tourism development carried out by the Mamuju Regency Culture and Tourism Office, it is still experiencing various kinds of obstacles, such as poor tourist attraction facilities, not yet using internet-based tourism attraction information, no Regional Tourism Development Master Plan (RIPPDA) active in helping the development of tourism and other issues.

In developing the potential of the Tapandullu Beach Tourism Object in Mamuju Regency, many factors influence the success or failure of its development, which has a lot of tourism potential which includes natural tourism. The Government of Mamuju Regency until now continues to carry out promotions for the introduction of its tourism, which every year has increased quite effectively even though it is not widely known by all people.

A number of supporting factors in the development of Tapandullu Beach tourism in Mamuju Regency include: first, strategic regional potential, areas such as Mamuju Regency which have a wealth of natural and cultural resources should be utilized by the community and government because it is not impossible that Mamuju Regency will is one of the main tourist destinations in West Sulawesi Province because of its preserved cultural diversity and natural wealth. Mamuju Regency also has a strategic location. Each region has various potentials that can be used as a basis for efforts to maintain the welfare standards that have been achieved by its citizens or can be developed to improve welfare or life at a better level.

Second, tourism support facilities, Mamuju regency has the availability of tourism support facilities that support the running of tours for tourists visiting Mamuju Regency such as the availability of restaurants, banks, airports, terminals, ports, travel agents. Even though until now there has been no cooperation with the local government. however, this facility still contributes to supporting tourism activities in Mamuju Regency. Tapandullu beach tourism object has the availability of supporting tourism facilities that are quite supportive. 
The three active roles of the community, the role of the community around the Tapandullu coastal area is quite large, the majority of people in the area around the Tapandullu beach have a role in promoting Tapandullu beach tourism starting from delivery from mouth to mouth to social media, besides that the surrounding community also often does community service in improving road access towards Tapandullu beach tour.

Furthermore, the inhibiting factors in the development of Tapandullu Beach tourism in Mamuju Regency include: first policy, changes in this new period affect the direction of policy in regional development planning in Mamuju Regency. So that the efforts made by the Mamuju Regency Tourism and Culture Office were not optimal due to the development planning policies of the previous Regent's government. The absence of a Perda RIPPDA Mamuju Regency (Regional Tourism Development Master Plan) 2016-2021 which guides the implementation of tourism development, has also become an obstacle in the development of tourism in Mamuju Regency in recent years.

The second is the budget, which is one of the factors inhibiting efforts to develop Tapandullu beach tourism by the Department of Culture and Tourism in Mamuju Regency because the source of funds to finance tourism development in Mamuju Regency is very dependent on the Regional Budget (APBD) of Mamuju Regency.

The three promotions are seen based on existing data sources from the Department of Culture and Tourism of Mamuju Regency, in 2016 the tourism attractions that were promoted were Karampuang Island, So'do Bath, Tamasapi Waterfall, and Mamuju Traditional House, then in 2017 the Tourism Attraction that was promoted also not much different, it's just that in 2018 the Mamuju Traditional House was no longer promoted as a tourist attraction in Mamuju Regency.

The fourth is Human Resources, explaining that the Culture and Tourism Office of the community managing Tourist Attractions also has low quality, this is due to the lack of public knowledge about the benefits of tourism for people's lives. Human resources for managing tourist attractions are also of low quality, this is due to the lack of public knowledge about the benefits of tourism for people's lives (Febrianti, 2017).

Fifth, infrastructure and accessibility in terms of tourism infrastructure development that takes into account the conditions and location will increase the accessibility of a tourist attraction which in turn will increase the attractiveness of the tourist attraction itself, access to Tapandullu beach is still inadequate, there are still some roads that have not been paved and lack of signs and directions to that location.

The development strategy carried out by the Tourism and Creative Economy Office is a strategy for product development, institutions and human resources, marketing, and environmental management. The local government has not developed and managed the Tapandullu coastal area as a tourist area optimally, this is due to the very minimal available budget (Wattimena, 2017). The development of the vision and mission of the Mamuju Regency Tourism and Culture Office is one of the stages in the formulation of the Tapandullu coastal tourism development strategy. The development of coastal areas into coastal tourism objects is based on the vision and mission that has been prepared, in other words, the development of coastal tourism must be in accordance with the vision and mission.

Based on the identification of opportunities, threats, internal strengths, and weaknesses, it shows that the opportunities and strengths are greater than the threats and weaknesses they have so that the Mamuju Regency Tourism and Culture Office must be able to optimize the development of coastal areas as a coastal tourism object. One way to formulate a strategy is by conducting a SWOT analysis. 
To determine the right strategy in tourism development, after SWOT identification is carried out, a way is needed to minimize weaknesses and threats (Nawawi, 2005). Weaknesses in the tourism development strategy are the internal tourism Human Resources that have not met several criteria both in quality and quantity, limited tourism facilities and infrastructure such as road access, and limited funds. Weaknesses related to internal tourism Human Resources can be overcome by organizing training, seminars, and other forms that can increase capacity and knowledge related to tourism development. In terms of quantity, local governments can recruit new Human Resources by meeting the established standards and criteria. One example is by conducting HR recruitment.

Furthermore, to overcome the limited facilities and infrastructure, for example regarding roads, a repair process has been carried out. Access roads to tourism objects should be improved by the Regional Government to facilitate tourists. Furthermore, regarding the limited funds, the Mamuju Regency Tourism and Culture Office has tried to raise funds and establish cooperation with other departments related to tourism activities, for example, the Ministry of Tourism and Creative Economy, the Department of Transportation, and Bina Marga. Apart from that, cooperating with the private sector will also minimize the limited funds for providing tourism facilities and infrastructure.

To realize the development of coastal tourism in Mamuju regency, important things are needed to do so that the development of Tapandullu coastal tourism can run well, is to compile a Grand Design and Roadmap for Tourism Development Governance which contains several strategies, including: (1) improving the basis of tourism development policies through a framework using a strategic management approach; (2) strengthening the multi-disciplinary approach in tourism development; (3) increasing the tourism attractions offered and (5) strengthening Mamuju Regency to become a tourism destination.

The first strategy, in order to implement strategies related to strategic management approaches, both central and local governments need to improve the basic foundation of tourism development policies which include, among others: improving tourism statistics data in Mamuju Regency. In this connection, the government needs to establish a "West Sulawesi Tourism Forum" which regularly holds meetings between stakeholders who have the main tasks and functions of tourism development in Mamuju Regency from the central, provincial to regency and city levels including tourism industry players. The purpose of this forum is to discuss important issues and improve coordination between the business world, central government, provinces, regencys, and cities in order to strengthen Indonesia's position as a destination country for world tourism: (1) increasing synergy between the marine economic sector and industry is a high priority because it is the main key in coastal tourism development. (2) making environmental and climate change policies. (3) create a Sustainable Development strategy

Second Strategy, The importance of a multi-disciplinary approach in tourism development in Mamuju Regency. For this reason, the following steps need to be taken: (1) strengthening cooperation and coordination between institutions that have duties and functions in tourism development. Various development policies have an influence on the creation of entrepreneurship. In this connection, tourism development policies need to be aligned with regional economic policies that will be developed into tourist destinations. This policy is expected to provide optimal tourism development results. Tourism depends on price stability. Tourism benefits from a low-tax fiscal policy, a business framework based on statutory regulations, and reduced red tape. Opening the market is one important aspect that will generate incentives for tourism actors to innovate so that the company's competitiveness will increase. (2) Improve coordination and cooperation policies at the provincial and regency/city 
levels. The main objective of this policy is to increase collaboration between various policies. Here are some policies that are important in developing coastal tourism.

The third strategy, improve the quality of tourism attractiveness. In order to increase competitiveness as a tourist destination, it is necessary to improve the quality of tourism attractiveness. The main responsibility for improving the quality of attractiveness is companies engaged in developing tourism attractions. The government provides support to companies by facilitating, among others, in the form of innovations, cooperation, and investment incentives for coastal tourism development.

The fourth strategy is to strengthen the vision and mission of Mamuju regency to become a domestic and world tourism destination. The main objective of this strategy is to strengthen marketing coordination from various groups including the business world at the central, central, and regional levels. To that end, important policy steps include: Increasing the Role of the Government. Within the framework of globalization, Mamuju Regency needs a tourism organization capable of providing services for an impressive and integrated market presence. This requires cooperation in the tourism sector between the national and regional levels. In addition, in global competition, it is necessary to pay attention to the small business industry. In the framework of the division of labor between local and regional tourism organizations, the main task of the government is to develop new products and markets, strengthen the coordination function, provide advisory support in the development of international valuable products.

Coordination and cooperation in promoting coastal tourism by the government. National tourism marketing is one of the important key factors which cannot be separated from promotion. The purpose of this activity is to strengthen coordination and cooperation between national tourism actors and other institutions that are responsible for promoting Indonesia as a country that has great economic potential, especially coastal tourism (Adam, 2018).

\section{Conclusion}

Policies in developing the coastal area as a tourist destination in the Mamuju Regency area by increasing the promotion of regional tourism in Mamuju Regency, developing environmentally-based productive tourism, fostering an active role for the community to participate in building the tourism sector, and increasing the role of local government, private sector and society in development Tourism in Mamuju Regency. Factors that influence the development of tourism, namely the supporting factors in the management of tourist objects, namely the potential of the area and the active role of the community so that they can develop and build a tourist attraction for Tapandullu Beach that is better and can attract the attention of tourists. While the inhibiting factors in Tapandullu Beach Tourism Governance are inadequate facilities and infrastructure and limited budget so that it hinders the process of developing the Tapandullu Beach tourism object. The managerial strategy for developing tourist beach tourism is realized in the form of strengthening the mass tourist market segment and developing the tourism market segment to optimize the development of coastal tourism destinations. It is hoped that the Mamuju regency government will make a strategy for the development of an integrated, synergistic, sustainable, and sustainable marketing partnership in the development of coastal areas to become tourist attractions.

\section{References}

Adam, M. B. (2018). Strategi Pengembangan Pariwisata Pesisir Di Kawasan Taman Wisata Pantai Ngliyep Kabupaten Malang (Doctoral dissertation, Institut Teknologi Sepuluh Nopember). 
Adrianus, A., \& Labuda, R. (2018). Strategi Pengembangan Parawisata Pesisir Di Desa Benung Kabupaten Kepualauan Sangihe Provinsi Sulawesi Utara. Jurnal Kebijakan Sosek, 8(1), 53-63.

Choi, H. C., \& Sirakaya, E. (2006). Sustainability indicators for managing community tourism. Tourism management, 27(6), 1274-1289.

Dredge, D. (2006). Policy networks and the local organisation of tourism. Tourism management, 27(2), 269-280.

Edgell Sr, D. L. (2019). Managing sustainable tourism: A legacy for the future. Routledge.

Febrianty, I. (2017). Strategi Pengembangan Wisata Pesisir Pantai: Studi Kasus Desa Batu Lima, Kuala Tambangan Kabupaten Tanah Laut Provinsi Kalimantan Selatan. Dinamika Maritim, 6(1), 40-46.

Heryati, Y. (2019). Potensi Pengembangan Obyek Wisata Pantai Tapandullu Di Kabupaten Mamuju. GROWTH Jurnal Ilmiah Ekonomi Pembangunan, 1(1), 56-74.

Joppe, M. (1996). Sustainable community tourism development revisited. Tourism management, 17(7), 475-479.

Liu, Z. (2003). Sustainable tourism development: A critique. Journal of sustainable tourism, $11(6), 459-475$.

Milne, S., \& Ateljevic, I. (2001). Tourism, economic development and the global-local nexus: Theory embracing complexity. Tourism geographies, 3(4), 369-393.

Nawawi, H. (2005). Manajemen Strategik. Yogyakarta: Gadjah Mada Pers.

Northcote, J., \& Macbeth, J. (2006). Conceptualizing yield: Sustainable tourism management. Annals of Tourism Research, 33(1), 199-220.

Nyoman, P. (2003). Ilmu Pariwisata sebuah Pengantar Perdana. Jakarta: Pradnya Paramita.

Rogerson, C. M. (2020). Using municipal tourism assets for leveraging local economic development in South Africa. Bulletin of Geography. Socio-economic Series, 48(48), 47-63.

Wattimena, R. A. (2017). Strategi Pengembangan Pesisir Pantai Desa Liang Sebagai Kawasan Objek Pariwisata. Manajemen dan Bisnis, 1(1).

Wilson, S., Fesenmaier, D. R., Fesenmaier, J., \& Van Es, J. C. (2001). Factors for success in rural tourism development. Journal of Travel research, 40(2), 132-138. 